\title{
ARTIGOS
}

\section{Caracterização morfofisiológica e análise de PCR-SSCP de isolados de Phytophthora da acácia-negra na região Sul do Brasil}

\author{
Tatiane Cristina Albuquerque Alves ${ }^{1}$, Álvaro Figueredo dos Santos ${ }^{2}$, Dauri José Tessmann ${ }^{1}$, João Batista Vida ${ }^{1}$, \\ Ricardo Harakava ${ }^{3}$
}

\begin{abstract}
${ }^{1}$ Universidade Estadual de Maringá, Av. Colombo 5790, CEP 87020-900 Maringá, PR; ${ }^{2}$ Embrapa Florestas, Caixa Postal 319, CEP 83411-000 Colombo, PR.; ${ }^{3}$ Instituto Biológico, Av. Conselheiro Rodrigues Alves 1252, CEP 04014002, São Paulo, SP.

Autor para correspondência: Álvaro Figueredo dos Santos (alvaro@cnpf.embrapa.br)

Data de chegada: 20/06/2010. Aceito para publicação em: 03/06/2011.
\end{abstract}

\section{RESUMO}

Alves, T.C. A.; Santos, A.F. dos; Tessmann, D.J; Vida, J.B.; Harakava, R. Caracterização morfofisiológica e análise de PCR-SSCP de isolados de Phytophthora da acácia-negra na região Sul do Brasil. Summa Phytopathologica, v.37, n.3, p.92-97, 2011.

O objetivo do trabalho foi caracterizar isolados de Phytophthora da acácia-negra (Acacia mearnsii) provenientes do Sul do Brasil, com base em características fenotípicas tais como morfologia, crescimento micelial, características das culturas, compatibilidade sexual e patogenicidade, e em perfis de polimorfismo de conformação de fita simples $(\mathrm{SSCP}=$ Single Strand Conformation Polymorphism $)$ da região ITS-gene $5.8 \mathrm{~S}$ do rDNA. Os isolados apresentaram esporângios com papilas proeminentes, arranjo dos esporângios irregularmente simpodial, culturas heterotálicas com presença de anterídios anfígenos, presença de clamidósporos e crescimento micelial em temperatura acima de $35^{\circ} \mathrm{C}$, permitindo a classificação dos 12 isolados como P. nicotianae. Todos os isolados foram patogênicos, causando necrose em ramos de acácia-negra, sem formação de goma, com diferenças significativas de agressividade $(\mathrm{p}=0,05)$. Duas populações podem ser distinguidas em P. nicotianae da acácia negra pela análise PCR-SSCP do rDNA; no entanto essa separação não apresenta aparente correlação com características fenotípicas.

Palavras-chave adicionais: Gomose, Oomycetes, patologia florestal

\section{ABSTRACT}

Alves, T.C. A.; Santos, A.F. dos; Tessmann, D.J; Vida, J.B.; Harakava, R. Morphophysiological characterization and PCR-SSCP analysis of Phytophthora isolates from black wattle in Southern Brazil. Summa Phytopathologica, v.37, n.3, p.92-97, 2011.

The aim of this study was to characterize Phytophthora isolates from black wattle (Acacia mearnsii) in Southern Brazil, based on phenotypic traits such as morphology, mycelial growth, cultural features, sexual compatibility and pathogenicity, as well as on single strand conformation polymorphism (PCR-SSCP) of rDNA ITS-gene $5.8 \mathrm{~S}$ region. The isolates presented sporangia with prominent papilla, irregularly sympodial sporangia, heterothalic cultures with amphigynous antheridia, presence of chlamydospore and mycelial growth at temperature above $35^{\circ} \mathrm{C}$, allowing the classification of all 12 isolates as P. nicotianae. All isolates were pathogenic to black wattle, causing necrosis on stems without gum formation, with significant differences on aggressiveness $(\mathrm{P}=0.05)$. Two populations of $P$. nicotianae from black wattle can be distinguished based on PCR-SSCP analysis of rDNA; however, this separation has no apparent correlation with phenotypic traits.

Keywords: gummosis, oomycetes, forest pathology

No Brasil, e em outros países produtores de acácia-negra (Acacia mearnsii De Wild), como a África do Sul e alguns países asiáticos, o principal problema fitossanitário da cultura é a ocorrência de uma doença conhecida como gomose. A gomose da acácia-negra danifica a casca, principalmente nas porções basal e mediana do tronco, chegando a causar prejuízos econômicos pela diminuição no aproveitamento da casca e, em casos mais extremos, pela morte das árvores (19).

$\mathrm{Na}$ África do Sul, Zeijlemaker (26), caracterizou parte dos sintomas como sendo causados por Phytopthora nicotianae Breda de Haan. Anos mais tarde, mais duas espécies associadas a esta doença foram relatadas por Roux \& Wingfield (17) P. meadii Mc Rae e P. boehmeriae Sawada. Os primeiros relatos da doença no Brasil foram feitos há mais de quarenta anos, apesar disso, apenas em 2005, Santos et al. (19) conseguiram associar a espécie $P$. nicotianae com os sintomas da gomose da acácia-negra. No ano seguinte, Santos et al. (18) relataram à ocorrência de uma sintomatologia diferenciada em algumas plantações no município de Piratini (RS), sendo constatado o envolvimento da espécie $P$. boehmeriae na etiologia da gomose.

Phytophthora é um gênero complexo com mais de 60 espécies descritas (1, 4). Embora compartilhem muitas características 
morfológicas em comum com os fungos, evolucionariamente, são mais intimamente relacionados às algas marrons e plantas do que aos fungos verdadeiros (14).

Um dos maiores problemas no estudo das espécies de Phytophthora reside em sua taxonomia $(13,22)$. Na década de 60 , Waterhouse (24) separou as espécies de Phytophthora em seis grupos, baseados numa série de parâmetros morfológicos e fisiológicos, marcando um avanço nos estudos de taxonomia do gênero, sendo este agrupamento usado e aceito até os dias atuais (4).

A análise de polimorfismo de conformação de fita simples (SSCP = Single Strand Conformation Polymorphism) da região ITS-gene 5.8S do rDNA é um método de abordagem molecular que tem-se mostrado válido para estudos de caracterização de populações de isolados ou de espécies de Phytophthora (7, 9, 14, 25). Dessa forma, visando um melhor conhecimento da etiologia da gomose da acácia negra no Brasil a fim de subsidiar a seleção de genótipos resistentes à doença, o objetivo deste trabalho foi caracterizar isolados de Phytophthora com base em características morfofisiológicas e na análise do DNA ribossomal do patógeno.

\section{MATERIAL E MÉTODOS}

Os trabalhos foram conduzidos nos laboratórios de Fitopatologia do Departamento de Agronomia da Universidade Estadual de Maringá, PR e da Embrapa Florestas em Colombo, PR. Os isolados de culturas puras de Phytophthora sp. utilizados neste trabalho foram obtidos da coleção de Phytophthora de espécies florestais da Embrapa Florestas (Tabela 1).

O teste de patogenicidade foi realizado em ramos destacados de árvores de acácia-negra, com aproximadamente seis anos de idade. Foram utilizados ramos com $25 \mathrm{~cm}$ de comprimento e cerca de $1,5 \mathrm{~cm}$ de diâmetro, com as extremidades parafinadas. Os ramos foram colocados em bandejas com fundo forrado de papel umedecido em água destilada. A inoculação foi realizada em dois pontos eqüidistantes, substituindo-se discos da casca com $5 \mathrm{~mm}$ de diâmetro por discos de meio CA com micélio dos isolados, com cinco dias de incubação. Os pontos de inoculação foram protegidos com algodão embebido em água destilada esterilizada para evitar o ressecamento. As bandejas foram revestidas com plástico transparente, e mantidas em ambiente de laboratório. $\mathrm{O}$ tratamento testemunha foi inoculado apenas com discos do meio de cultura CA. A patogenicidade foi avaliada dez dias após a inoculação, através da raspagem da região inoculada para a observação dos sintomas. A agressividade dos isolados foi avaliada juntamente com a patogenicidade, consistindo na medição do comprimento das lesões. O delineamento utilizado foi inteiramente casualizado com dez repetições por isolado. Para a análise de variância e o teste de Scott-Knott para agrupamento, foi utilizado o pacote estatístico SISVAR (5).

Para o estudo das características culturais, foi considerada a forma da colônia em meio CA (200 g de cenoura; 17 g de ágar e 1000 mL de água destilada) por sete dias a $24{ }^{\circ} \mathrm{C}$, sendo a avaliação realizada de acordo com Erwin \& Ribeiro (4). As dimensões dos esporângios e clamidósporos foram determinadas por micrometria através de lâminas preparadas com lactofenol contendo o micélio de cada isolado. Para obtenção de micélio com as estruturas desejadas discos de meio contendo micélio dos isolados foram cultivados em meio líquido com extrato de solo ( $10 \mathrm{~g}$ de solo; $1000 \mathrm{~mL}$ água destilada) não autoclavado por 96 horas à $24^{\circ} \mathrm{C}$ sob regime de luz. Foram medidas 50 unidades de cada uma das estruturas para cada isolado. As mesmas placas foram visualizadas em microscópio a fim de se observar a ontogênia e morfologia dos esporângios.

Para determinar a natureza heterotálica dos isolados de Phytophthora foram realizados os pareamentos individuais entre os isolados e os padröes $\mathrm{A}_{1}$ (isolado 61) e $\mathrm{A}_{2}$ (isolado 65). Após o pareamento, as placas foram incubadas a $25{ }^{\circ} \mathrm{C}$ em BOD por cinco dias, em condições de escuro. As avaliações consistiram na observação da presença ou ausência de oósporos nas placas para cada tipo de pareamento. Foram preparadas lâminas com lactofenol das placas contendo oósporos, para determinar as dimensões das estruturas sexuais e também a morfologia do anterídio, caracterizando-os como anfígenos ou paráginos.

Foi testado o efeito da temperatura na taxa de crescimento micelial dos isolados. Placas de Petri com meio de cultura CA contendo ao centro um disco de meio com micélio dos isolados foram incubadas durante sete dias nas temperaturas de $8,12,16,20,24,28,32$ e $36^{\circ} \mathrm{C}$, em condições de escuro contínuo (14). O crescimento radial das colônias foi medido com três, cinco e sete dias, obtendo-se a média para cada repetição. $\mathrm{O}$ delineamento utilizado foi inteiramente casualizado, em esquema fatorial, com três repetições/isolado para cada temperatura.

Para a análise de PCR-SSCP empregou-se o protocolo de Kong et al. $(10,11)$ com modificações. Para isso, os isolados foram cultivados em meio líquido de cenoura (200 g de cenoura; $1000 \mathrm{~mL}$ de água destilada) por sete dias em temperatura ambiente. Após esse período, o micélio foi separado por filtragem e armazenado em microtubos de $1,5 \mathrm{ml} \mathrm{a}-4{ }^{\circ} \mathrm{C}$. A extração de DNA dos isolados foi baseada no Kit Plant DNAzol (Invitrigen). Aproximadamente $100 \mathrm{mg}$ da massa micelial dos isolados foram macerados em $\mathrm{N}_{2}$ líquido e transferidos para microtubos de $1,5 \mathrm{ml}$ onde foram adicionados $300 \mu \mathrm{L}$ do reagente Plant DNAzol. Em seguida, as amostras foram homogeneizadas e os tubos incubados em banho-maria a $25^{\circ} \mathrm{C}$ por 5 minutos. Na sequência, foram adicionados $300 \mu \mathrm{L}$ de clorofórmio e os tubos permaneceram em banho-maria a $25{ }^{\circ} \mathrm{C}$, por mais 5 minutos. As amostras foram centrifugadas a $12.000 \mathrm{x}$ g por 4 minutos, o sobrenadante removido para microtubos limpos e adicionado $225 \mu \mathrm{L}$ de etanol $100 \%$ para a precipitação do DNA. Novamente, as amostras foram centrifugadas a $5.000 \mathrm{x}$ g por 4 minutos descartando-se o sobrenadante. Em seguida, adicionou-se $300 \mu \mathrm{L}$ da mistura Plant DNAzol mais etanol $70 \%$ na proporção de 1:0,75 (v:v), os tubos foram homogeneizados e armazenados a temperatura ambiente por 5 minutos. Para lavagem do pellet formado, as amostras foram centrifugadas a $5.000 \mathrm{x} \mathrm{g}$ por 4 minutos, o sobrenadante descartado e adicionado aos tubos $300 \mu \mathrm{L}$ de etanol $75 \%$, seguido de nova centrifugação e descarte do sobrenadante. Os tubos foram colocados em capela de fluxo laminar até completa evaporação do etanol. O DNA foi ressuspendido adicionando-se 70 $\mu \mathrm{L}$ de tampão TE (10 mM Tris-HCl pH 7,5; 0,1 mM EDTA) e as amostras armazenadas a $4{ }^{\circ} \mathrm{C}$.

A reação de PCR foi executada com volume total de $25 \mu \mathrm{L}$, contendo DNA genômico, $50 \mathrm{mM} \mathrm{MgCl}_{2}, 10 x$ tampão de PCR, $2 \mathrm{mM}$ de cada um dos dNTP, dATP, dCTP, dGTP e dTTP, 1 U de Taq polimerase (Promega) e $1 \mathrm{mM}$ de cada um dos primers ITS6 e ITS7 (Kong et al., 2003). As reações de PCR consistiram de uma desnaturação inicial de $96^{\circ} \mathrm{C}$ por $2 \mathrm{~min}$, seguida de 30 ciclos de $30 \mathrm{seg}$ a $94{ }^{\circ} \mathrm{C}, 45$ seg $55{ }^{\circ} \mathrm{C}$ e 1 min a $72{ }^{\circ} \mathrm{C}$, com um período extra de extensão de $72{ }^{\circ} \mathrm{C}$ por $10 \mathrm{~min}$. As reações de amplificação foram conduzidas em um termociclador Tpersonal Whatman Biometra (Biometra $\mathrm{GmbH}$, Goettingen, Alemanha). Uma alíquota do produto de PCR foi misturada com igual volume de solução desnaturante (95 $\%$ formamida, $20 \mathrm{mM}$ EDTA e $0,05 \%$ de azul de bromofenol) e aquecido a $96{ }^{\circ} \mathrm{C}$ por $10 \mathrm{~min}$, logo após resfriadas em gelo. O produto 
de PCR desnaturado foi então submetido à eletroforese em gel de poliacrilamida a $8 \%$, por $4 \mathrm{~h}$ a $200 \mathrm{~V}$. Para a visualização das bandas, o gel foi corado em nitrato de prata e fotografado sob luz branca. Os padrões eletroforéticos de SSCP dos isolados, foram analisados e comparados entre si.

\section{RESULTADOS E DISCUSSÃO}

Todos isolados mostraram-se patogênicos a acácia-negra, formando lesões nos ramos inoculados. A testemunha apresentou escurecimento da região circunvizinha ao ponto de inoculação, devido à injúria causada pela retirada do tecido. Os sintomas observados nos ramos inoculados foram escurecimento sem exsudação de goma. Os mesmos sintomas foram observados por Santos et al. (19) ao inocularem mudas de acácianegra com isolados de P. nicotianae. Quanto à agressividade dos isolados houve diferença significativa para o tamanho das lesões, quando agrupados pelo teste de Scott-Knott $(\mathrm{p}=0,05)$. Todos os isolados diferiram da testemunha. Os dados foram transformados para logaritmo, e estão representados na Figura 1.

Em meio CA as colônias apresentaram micélio aéreo variando de denso a pouco denso, com padrões de colônia rosáceo, estrelado para rosáceo, ligeiramente estrelado e ligeiramente rosáceo. Muniz et al. (15), relataram a presença de cultura com aspecto cotonoso para isolados de $P$. nicotianae cultivados em meio de cultura CA. Por sua vez, Santos et al. (19) observaram a presença de culturas petalóides em isolados de $P$. nicotianae, também cultivados em meio de cultura CA. Esta variação entre isolados da mesma espécie pode ser atribuída ao genótipo de cada isolado, cuja expressão fenotípica está relacionada com as interações entre genótipo e condições do meio, principalmente meio de cultura e temperatura de incubação.

Esporângios apresentaram-se papilados, persistentes, formados individualmente ou algumas vezes irregularmente simpodial, com forma predominantemente ovóide (Figura 2). As medidas de comprimento $\mathrm{x}$ largura variaram de 27,90 - 74,74 x 21,70 - 52,70 $\mu \mathrm{m}$ (média 53,67 x $37,67 \mu \mathrm{m})$, com relação $\mathrm{C} / \mathrm{L}$ de $1,43: 1$, profundidade média da papila de 7,02 $\mu \mathrm{m}$ e abertura do poro $7,15 \mu \mathrm{m}$. Valores de 33,3-56,0 $\mu \mathrm{m}$ para comprimento e $24,5-35,0 \mu \mathrm{m}$ para largura foram observados por Santos et al. (19) em esporângios de P. nicotianae da acácia-negra. Na chave taxonômica descrita por Stamps et al. (21), o comprimento dos esporângios de P. nicotianae aparece entre $45-75 \mu \mathrm{m}$. As dimensões dos esporângios têm se mostrado uma característica muito

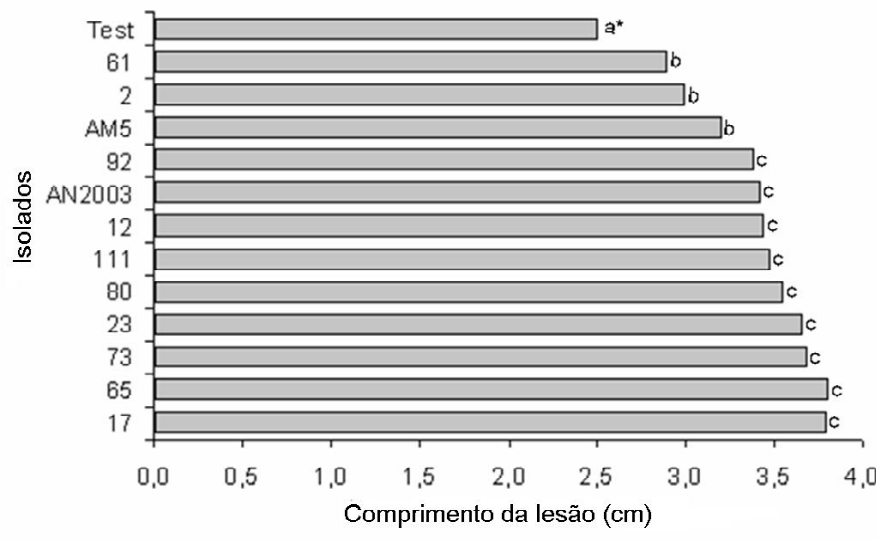

Figura 1. Comprimento das lesões em ramos destacados de acácia-negra inoculados com os isolados de Phytophthora sp. *Médias seguidas pela mesma letra não diferem entre si pelo teste de agrupamento Scott-Knott, a $5 \%$ de probabilidade . Test $=$ testemunha .

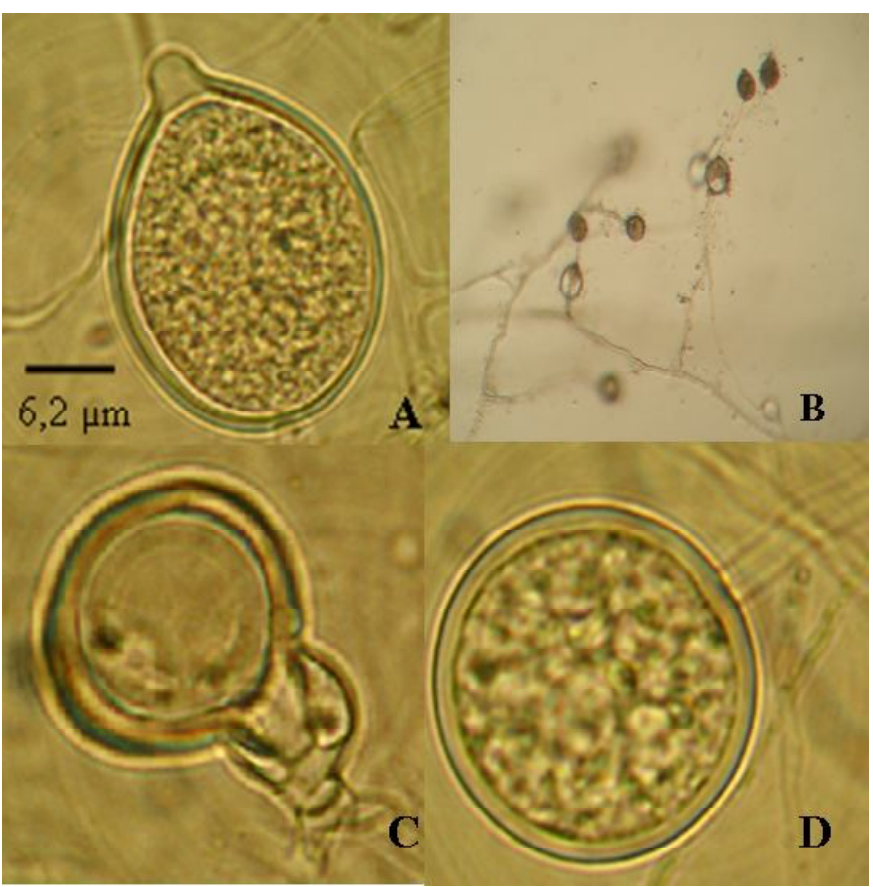

Figura 2. A: Esporângio; B: Arranjo irregularmente simpodial; C: Oósporo; D: Clamidósporo terminal.

variável dentro da espécie, devido às variações nos meios de cultura.

Os isolados produziram clamidósporos globosos, terminais e intercalares com diâmetro de 24,8 - 55,80 $\mu \mathrm{m}$ (média de 37,16 $\mu \mathrm{m}$ ) e espessura da parede de 1,55 - 6,20 $\mu \mathrm{m}$ (média 3,17 $\mu \mathrm{m}$ ) (Figura 2). Devido à morfologia dos clamidósporos não variarem apreciavelmente entre espécies, a significância deste caráter na taxonomia em grande parte fica limitada a sua presença ou ausência (4).

Nos isolados avaliados, a formação de gametângios em meio CA seguido da produção de oósporos se deu a partir do pareamento entre os dois grupos de compatibilidade após o quinto dia, sendo constatada a presença de anterídio anfígeno em todos os isolados (Figura 2). Os oogônios apresentaram diâmetro de 21,70 - 37,20 $\mu$ m (média de 29,29 $\mu \mathrm{m}$ ), os oósporos apresentaram-se globosos, apleróticos, com diâmetro de 15,50 - 32,55 $\mu \mathrm{m}$ (média 23,43 $\mu \mathrm{m}$ ). Resultados semelhantes foram apresentados por Santos et al. (19) quanto à presença de anterídio anfígeno em culturas pareadas de P. nicotianae mantidas no escuro,

Tabela 1. Relação dos isolados de Phytophthora da acácia-negra coletados na região Sul do Brasil e seus respectivos grupos de compatibilidade.

\begin{tabular}{llc}
\hline Isolados & Local & Grupo de compatibilidade \\
\hline 2 & Triunfo, RS & $\mathrm{A}_{1}$ \\
12 & Triunfo, RS & $\mathrm{A}_{2}$ \\
17 & Montenegro, RS & $\mathrm{A}_{1}$ \\
23 & Triunfo, RS & $\mathrm{A}_{2}$ \\
61 & Encruzilhada do Sul, RS & $\mathrm{A}_{1}$ \\
65 & Encruzilhada do Sul, RS & $\mathrm{A}_{2}$ \\
73 & Piratini, RS & $\mathrm{A}_{2}$ \\
80 & Piratini, RS & $\mathrm{A}_{2}$ \\
92 & Piratini, RS & $\mathrm{A}_{2}$ \\
111 & Canguçu, RS & $\mathrm{A}_{2}$ \\
AM5 & Ponta Grossa, PR & $\mathrm{A}_{1}$ \\
AN2003 & Colombo, PR & $\mathrm{A}_{2}$ \\
\hline
\end{tabular}


após o sexto dia de incubação.

Todos os isolados apresentaram culturas heterotálicas, sendo observada a presença dos dois grupos de compatibilidade $A_{1}$ e $A_{2}$ entre eles, e em alguns casos a ocorrência dos dois grupos de compatibilidade em isolados da mesma região (Tabela 1). De acordo com Goodwin (8), a ocorrência de isolados dos grupos $\mathrm{A}_{1}$ e $\mathrm{A}_{2}$ numa região incidindo sobre a mesma cultura aumentam as chances de reprodução sexuada $\mathrm{e}$ o surgimento de recombinantes, os quais podem apresentar melhores características de adaptabilidade ao meio.
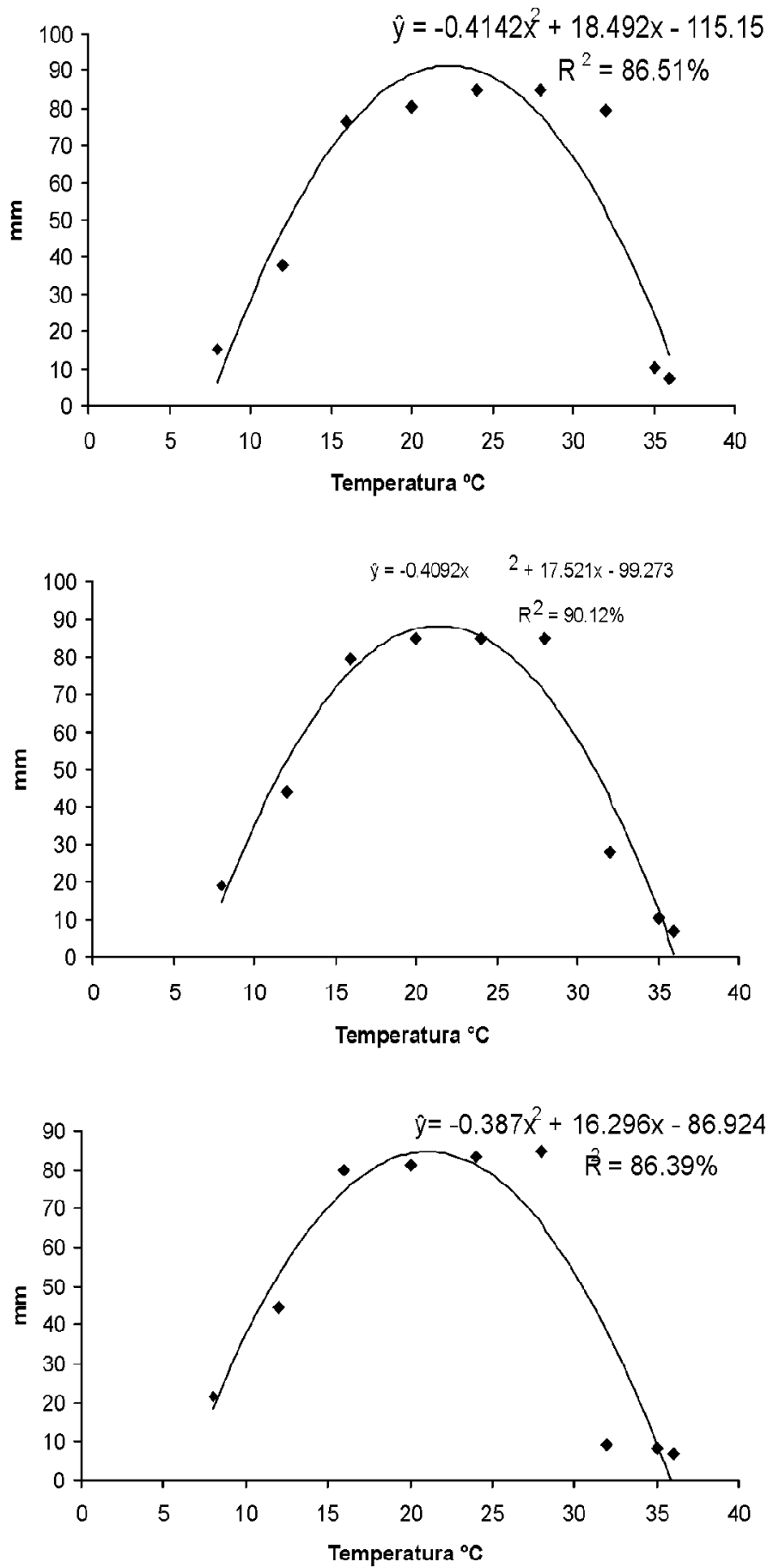

O efeito da temperatura no crescimento micelial dos isolados foi significativo, havendo variação tanto para temperatura como entre os isolados (Figura 3). Aos $36{ }^{\circ} \mathrm{C}$ houve pouco crescimento micelial, com o maior diâmetro das colônias sendo observado entre 20 e 28 ${ }^{\circ} \mathrm{C}$. Todos os isolados apresentaram crescimento a $8{ }^{\circ} \mathrm{C}$, exceto o isolado 111. Em isolados de P. nicotianae da acácia-negra, testados nos meios CA, BDA, e V-8 ágar, Santos et al. (19) não observaram crescimento micelial em nenhum dos meios a $36^{\circ} \mathrm{C}$, sendo a faixa de crescimento ocorrendo entre 10 a $35{ }^{\circ} \mathrm{C}$, e temperatura ótima
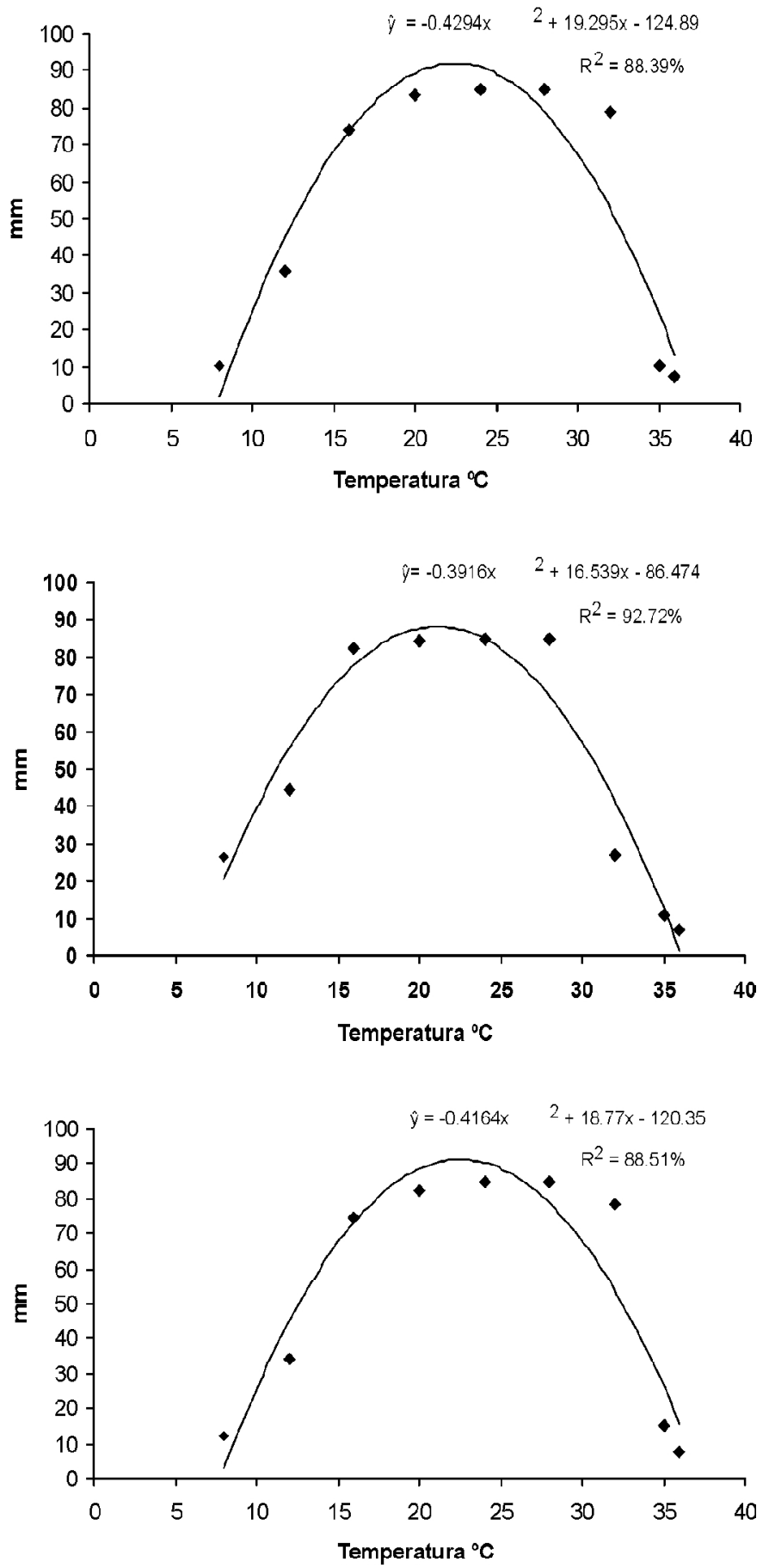

continua..

Figura 3. Equações ajustadas a partir do desdobramento da variável temperatura dentro de cada isolado. Crescimento micelial dos seguintes isolados de Phytophthora: 2 (A), 12 (B), 17 (C), 23 (D), 61 (E), 65 (F), 73 (G), 80 (H), 92 (I), 111 (J), AM5 (K) e AN2003 (L). 

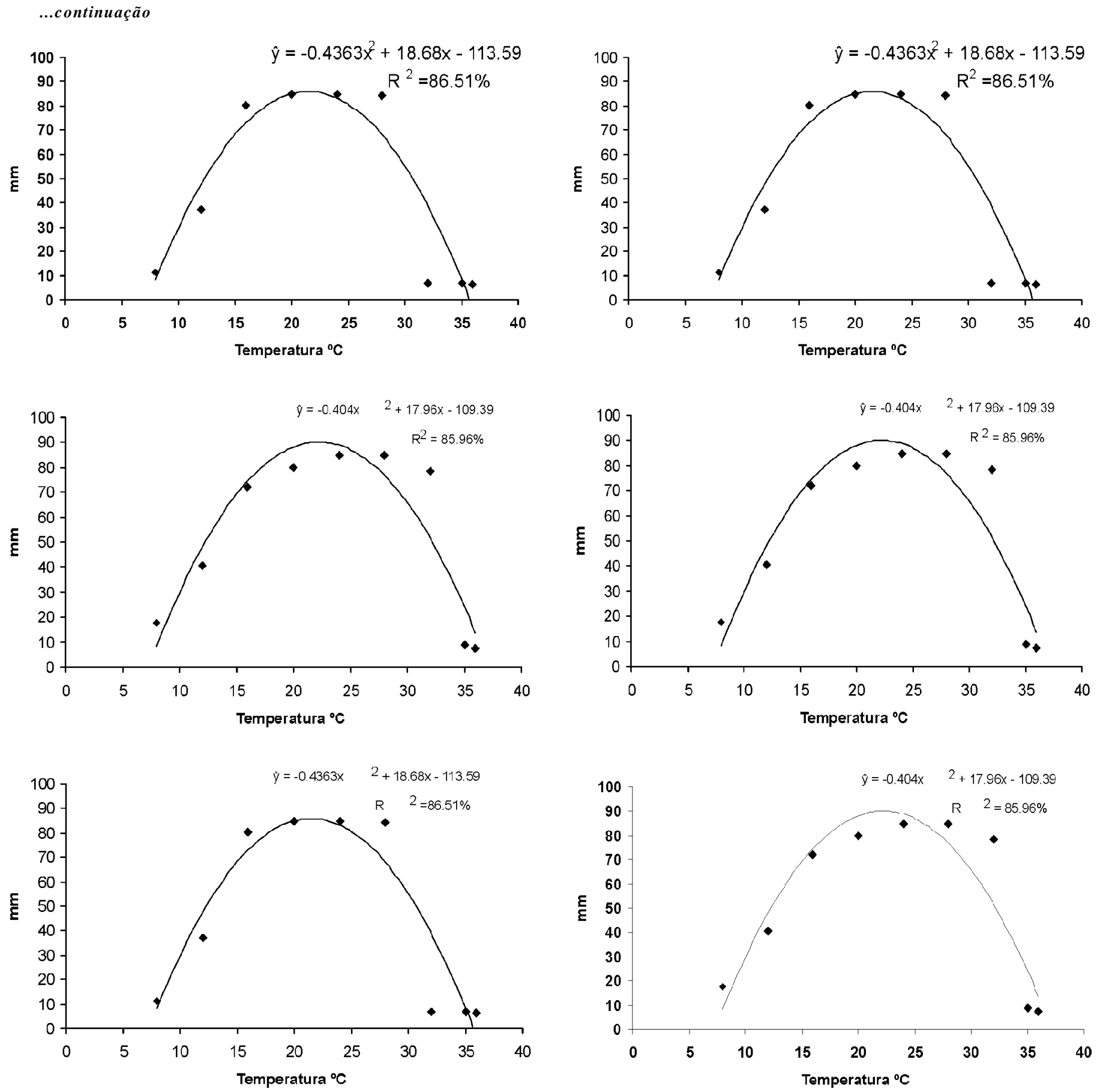

Figura 3. Equações ajustadas a partir do desdobramento da variável temperatura dentro de cada isolado. Crescimento micelial dos seguintes isolados de Phytophthora: 2 (A), 12 (B), 17 (C), 23 (D), 61 (E), 65 (F), 73 (G), 80 (H), 92 (I), 111 (J), AM5 (K) e AN2003 (L).

entre 24 e $32{ }^{\circ} \mathrm{C}$. Entretanto, Fisher et al. (6) estudando isolados de P. nicotianae patogênicos a lírio da paz (Spathiphyllum wallisi), constataram o crescimento micelial de isolados a $37{ }^{\circ} \mathrm{C}$, em meio BDA.

Assim sendo, as características morfofisiológicas descritas anteriormente permitiram classificar os 12 isolados como $P$. nicotianae com base nas seguintes características: esporângios com papilas proeminentes, arranjo dos esporângios irregularmente simpodial, culturas heterotálicas com presença de anterídios anfígenos, presença de clamidósporos e crescimento micelial em temperatura acima de $35^{\circ} \mathrm{C}$, conforme descrito por Waterhouse (24), Stamps et al. (21) e Erwin \& Ribeiro (4). Anteriormente a este estudo, Santos et al. (19) relataram no Brasil a ocorrência de $P$. nicotianae em acácia-negra no Brasil.

Os produtos de PCR com os primers ITS6 e ITS7 utilizados na análise de SSCP apresentaram cerca de 300 bp. A análise de SSCP dos produtos de PCR desnaturados resultaram em dois diferentes padrões de bandas entre os isolados de $P$. nicotianae, possibilitando separar estes isolados em dois grupos (Figura 4). Não se verificou correlação dessas populações com 


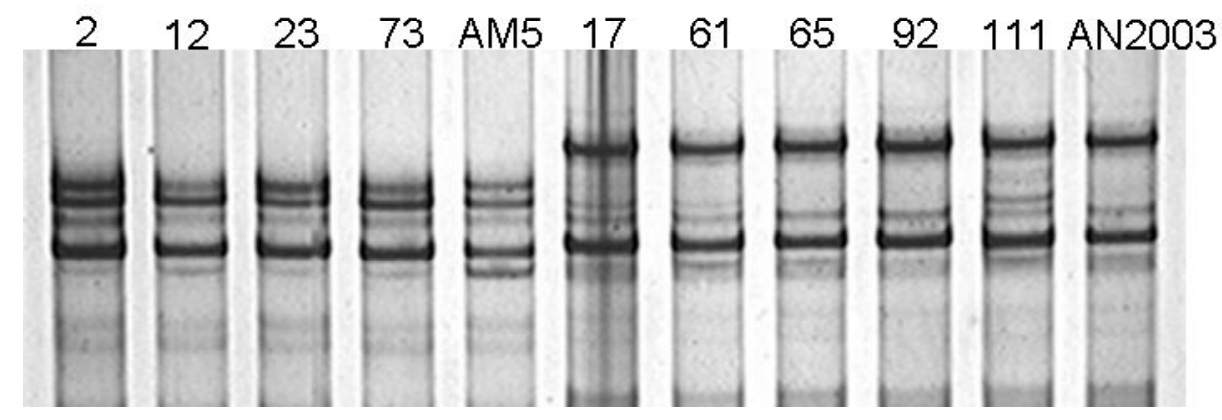

Figura 4. Padrões de SSCP da região ITS1 de isolados de Phytophthora nicotianae, evidenciando a presença de dois grupos entre os isolados. O nome dos isolados estão representados no topo das linhas.

agressividade ou outro atributo fenotípico dos isolados. Por outro lado, a presença dessas populações pode ser uma evidência de ocorrência de espécies filogenéticas em $P$. nicotianae na acácia negra, o que poderá ser confirmado pela análise de um maior número de locos informativos sobre filogenia de Phytophthora (2, 3, 8, 10, 12, 16, 20, 23).

\section{AGRADECIMENTOS}

Ao Conselho Nacional de Desenvolvimento Científico e Tecnológico (CNPq) e à Coordenadoria de Aperfeiçoamento de Pessoal de Nível Superior (CAPES) pelo apoio financeiro.

\section{REFERÊNCIAS BIBLIOGRÁFICAS}

1. Brasier, C.M.; Cooke, D.E.; Duncan, J.M. Origin of a new Phytophthora pathogen through interspecific hybridization. Proceedings of the National Academy Sciences, v. 96, p. 5878$5883,1999$.

2. Chowdappa, P.; Brayford, D.; Smith, J.; Flood, J. Identification of Phytophthora species affecting plantation crops by RFLP of PCR-amplified internal transcribed spacer regions of ribosomal RNA. Current Science, v. 85, n. 1, p. $34-36,2003$.

3. Cooke, D.E.; Drenth, A.; Duncan, J.M.; Wagels, G.; Brasier, C.M. A molecular phylogeny of Phytophthora and related oomycetes. Fungal Genetics and Biology, v. 30, p. 17 - 32, 2000.

4. Erwin, D.C.; Ribeiro, O.K. Phytophthora Diseases Worldwide. APS Press. St Paul. MN. USA, p. 562, 1996.

5. Ferreira, D.F. Sisvar - Sistema de Análise de Variância; Lavras: UFLA; 2006. Meio digital; http://www.dex.ufla.br/ danielff/ sisvar.zip. Acesso em 25. fev. 2009.

6. Fisher, I.H.; Martins, M.C.; Lourenço, L.A.; Abreu, F.M. Ocorrência de Phytophthora parasítica em lírio da paz no Brasil. Fitopatologia Brasileira, v. 29, n. 6, p. 690, 2005.

7. Foster, H.; Cummings, M.P.; Coffey, M.D. Phylogenetic relationships of Phytophthora species based on ribosomal ITS 1 DNA sequence analysis with an emphasis on Waterhouse groups $\mathrm{V}$ and VI. Mycological Research, n.104, p.1055-1061, 2000.

8. Goodwin, S.B. The Population Genetics of Phytophthora. Phytopathology, v. 87 , n. 4, p. $462-473,1997$

9. Hayden, K.; Rizzo, D.; Tse, J.; Garbelotto, M. Detection and quantification of Phytophthora ramorum from California Forests using a real-time polymerase chain reaction assay. Phytopathology, v. 94, p. $1075-1083,2004$.

10. Kong, P.; Hong, C.X.; Richardson, P.A.; Gallegly, M.E. Singlestrand conformation-polymorphism of ribosomal DNA for rapid species differentiation in genus Phytophthora. Fungal Genetics and Biology, n. 39, p.:238-249, 2003.

11. Kong, P.; Hong, C.X.; Tooley, P.W.; Ivors, K.; Garbelotto, M.;
Richardson, P. Rapid identification of Phytophthora ramorum using PCR-SSCP analysis of ribosomal DNA ITS-1. Letters in Applied Microbiology, v. 38, p. 433-439, 2004.

12. Kroon, L.P.N.; Bakker, F.T.; Van Den Bosch, G.B.M.; Bonants, P.J.M.; Flier, W.G. Phylogenetic analysis of Phytophthora species based on mitochondrial and nuclear DNA sequences. Fungal Genetics and Biology, n.41, p.766-782, 2004.

13. Luz, E.D.M.N.; Matsuoka, K. Taxonomia e sistemática do gênero Phytophthora. Revisão Anual de Patologia de Plantas, v. 4 p.297-328, 1996.

14. Martin, F.N.; Tooley, P.W. Phylogenetic relationships among Phytophthora species inferred from sequence analysis of mitochondrially encoded cytochrome oxidase I and II genes. Mycologia, n.2, p.269-284, 2003.

15. Muniz, M.F.S.; Queiroz, F.M.; Menezes, M. Caracterização de isolados de Phytophthora patogênicos a Citrus sinensis no Estado de Alagoas. Fitopatologia Brasileira, v.29, p.201-204, 2004.

16. Paim, M.C.A.; Luz, E.D.M.N.; Souza, J.T.; Cerqueira, A.O.; Lopes, J.R.M. Pathogenecity of Phytophthora species to Anthurium andraeanum in Brazil. Australasian Plant Pathology, v.35, p.275-277, 2006.

17. Roux, J.; Wingfield, M.J. Survey and virulence of fungi occurring on diseased Acacia mearnsii in South - Africa. Forest Ecology and Management, v. 99, p.327-336, 1997.

18. Santos, A.F, dos; Luz, E.D.M.N.; Souza, J.T. First report of Phytophthora boehmeriae on black wattle in Brazil. Plant Pathology, v. 55, p.813, 2006.

19. Santos, A.F. dos; Luz, E.D.M.N.; Souza, J.T. Phytophthora nicotianae: agente etiológico da gomose da acácia-negra no Brasil. Fitopatologia Brasileira, v.30, p.81-84, 2005.

20. Schneider, H. Métodos de análise filogenética: um guia prático. 2 ed. Ribeirão Preto. Holos Editora. 2003.

21. Stamps, D.J.; Waterhouse, G.M.; Newhook, F.J.; Hall, G.S. Revised tabular key to the species of Phytophthora. Mycological Papers, n.162, p.1-28, 1990.

22. Stukely, M.J.; Webster, J.L.; Ciampini, J.A.; Kerp, N.L.; Colquhoun, I.J.; Dunstan, W.A. Hardy, G.E.S.J. A new homothallic Phytophthora from the jarrah forest in Western Australia. Australasian Plant Disease Notes, n.2, p.49-51, 2007.

23. Villa, N.O.; Kageyama, K.; Suga, H. Phylogenetic relationships of Pythium and Phytophthora species based on ITS rDNA, cytochrome oxidase II and $\beta$-tubulin gene sequences. Mycologia, n.3, p.410-422, 2006.

24. Waterhouse, G.M. Key to the species of Phytophthora de Bary. Commonwealth Mycological Institute. Mycological papers, n.92, 22 p., 1963.

25. White, T.J.; Bruns, T.; Lee, S.; Taylor, J. Amplification and direct sequencing of fungal ribosomal RNA genes for phylogenetics. In: . Innis, M. A.; Gelfand, D.H.; Sninsky, J.J.; White, T.J. PCR protocols: a guide to methods and applications. eds. San Diego: Academic Press. p. 315 - 322, 1990.

26. Zeiljemaker, F.C.J. The gummosis of black wattle :a complex of disease. In: Watlle Research Institute (Pietermaritzburg, South Africa) Report 1967 - 68. Pietermaritzburg, p. 40 - 43, 1968. 